\title{
The therapeutic efficacy of water-soluble coenzyme Q1o in an experimental model of tacrolimus-induced diabetes mellitus
}

Yi Quan ${ }^{1,2}$, Kang Luo ${ }^{1,2}$, Sheng Cui ${ }^{1,2}$, Sun Woo Lim ${ }^{1,2}$, Yoo Jin Shin ${ }^{1,2}$, Eun Jeong Ko ${ }^{2,3}$, Ju Hwan Kim4, Sang J. Chung, 5 , Soo Kyung Bae ${ }^{6}$, Byung Ha Chung ${ }^{2,3}$, and Chul Woo Yang ${ }^{1,3}$

\begin{abstract}
${ }^{1}$ Transplant Research Center, ${ }^{2}$ Convergent Research Consortium for Immunologic Disease, ${ }^{3}$ Division of Nephrology, Department of Internal Medicine, Seoul St. Mary's Hospital, College of Medicine, The Catholic University of Korea, Seoul; ${ }^{4}$ Abtis Co. Ltd., Suwon; ${ }^{5}$ Sungkyunkwan University School of Pharmacy, Suwon; ${ }^{6}$ College of Pharmacy, The Catholic University of Korea, Bucheon, Korea
\end{abstract}

Received: August 13, 2019

Revised : September 22, 2019

Accepted: October 1, 2019

\section{Correspondence to}

Chul Woo Yang, M,D

Division of Nephrology, Department of Internal Medicine, Seoul St. Mary's Hospital, College of Medicine, The Catholic University of Korea, 222 Banpo-Daero, Seocho-gu, Seoul, o6591, Korea Tel: +82-2-2258-6851

Fax: +82-2-2258-6917

E-mail:yangch@catholic.ac.kr https://orcid.org/0000-00019796-636X
Background/Aims: Coenzyme $\mathrm{Q}_{10}\left(\mathrm{CoQ}_{10}\right)$ has antioxidant effects and is commercially available and marketed extensively. However, due to its low bioavailability, its effects are still controversial. We developed a water-soluble $\mathrm{CoQ}_{10}$-based micelle formulation $\left(\mathrm{CoQ}_{10}-\mathrm{W}\right)$ and tested it in an experimental model of tacrolimus (TAC)-induced diabetes mellitus (DM).

Methods: We developed $\mathrm{Co}_{10}-\mathrm{W}$ from a glycyrrhizic-carnitine mixed layer $\mathrm{CoQ}_{10}$ micelle preparation based on acyltransferases. TAC-induced DM rats were treated with either lipid-soluble $\mathrm{CoQ}_{10}\left(\mathrm{CoQ}_{10}-\mathrm{L}\right)$ or $\mathrm{CoQ}_{10}-\mathrm{W}$ for 4 weeks. Their plasma and pancreatic $\mathrm{CoQ}_{10}$ concentrations were measured using liquid chromatography-tandem mass spectrometry. The therapeutic efficacies of $\mathrm{CoQ}_{10}-\mathrm{W}$ and $\mathrm{Co}_{10}$-L on TAC-induced DM were compared using functional and morphological parameters and their effects on cell viability and reactive oxygen species (ROS) production were also evaluated in cultured rat insulinoma cells.

Results: The plasma $C_{0} Q_{10}$ level was significantly increased in the $C_{0} Q_{10}-W$ group compared to that in the $\mathrm{CoQ}_{10}-\mathrm{L}$ group. Intraperitoneal glucose tolerance tests and glucose-stimulated insulin secretion revealed that $\mathrm{CoQ}_{10}-\mathrm{W}$ controlled hyperglycemia and restored insulin secretion significantly better than $\mathrm{CoQ}_{10}-\mathrm{L}$. The TAC-mediated decrease in pancreatic islet size was significantly attenuated by $\mathrm{CoQ}_{10}-\mathrm{W}$ but not by CoQ10-L. TAC-induced oxidative stress and apoptosis were significantly more reduced by $\mathrm{CoQ}_{10}-\mathrm{W}$ than $\mathrm{CoQ}_{10}-\mathrm{L}$. Electron microscopy revealed that $\mathrm{CoQ}_{10}-\mathrm{W}$ restored TAC-induced attenuation in the number of insulin granules and the average mitochondrial area, unlike $\mathrm{CoQ}_{10}-\mathrm{L}$. In vitro studies showed that $\mathrm{CoQ}_{10}-\mathrm{L}$ and $\mathrm{CoQ}_{10}-\mathrm{W}$ both improved cell viability and reduced ROS production in TAC-treated islet cells to a similar extent.

Conclusions: $\mathrm{CoQ}_{10}-\mathrm{W}$ has better therapeutic efficacy than $\mathrm{CoQ}_{10}-\mathrm{L}$ in TAC-induced DM.

Keywords: Coenzyme Q10; Tacrolimus; Diabetes mellitus; Oxidative stress; Apoptosis

\section{INTRODUCTION}

Diabetes mellitus (DM) is the most common cause of end stage renal disease worldwide, and aggravation or development of DM after transplantation is a serious complication in solid organ transplant recipients [1]. 
Tacrolimus (TAC) is the most popular immunosuppressant but it causes several metabolic complications. These include TAC-induced DM, which is an important adverse effect in organ transplant recipients $[2,3]$. The mechanisms of TAC-induced DM are not well studied, but direct injury to pancreatic islet cells or impaired insulin signaling by TAC are regarded as the main pathogenesis methods, and oxidative stress plays a significant role in the process of TAC-induced pancreatic islet injury $[4,5]$. Thus, reducing TAC-induced oxidative stress is one of the important approaches for decreasing TAC-induced DM.

Coenzyme $\mathrm{Q}_{10}\left(\mathrm{CoQ}_{10}\right)$ is an electron transporter in the electron transport chain (ETC) that transports electrons from ETC complex I and II to complex III $[6,7]$. With its potential antioxidant effects [8-13], $\mathrm{CoQ}_{10}$ has been commercialized and is widely circulated in health care markets, but its therapeutic effect on diseases such as DM is still controversial due to its low bioavailability. The low bioavailability of $\mathrm{CoQ}_{10}$ is related to its hydrophobic chemical structure, and most of the circulating $\operatorname{CoQ}_{10}$ are in lipid-soluble form.

Thus, improving the bioavailability of $\mathrm{CoQ}_{10}$ is important for optimizing the use of this potential antioxidant. In this study, we developed water-soluble $\mathrm{CoQ}_{10}$ $\left(\mathrm{CoQ}_{10}-\mathrm{W}\right)$ to improve bioavailability and compared its effect with that of lipid-soluble $\mathrm{CoQ}_{10}\left(\mathrm{CoQ}_{10}-\mathrm{L}\right)$ in an experimental model of TAC-induced DM.

\section{METHODS}

\section{Development of $\mathrm{CoQ}_{10}-\mathrm{W}$}

Coenzyme $Q_{10}$ was purchased from Kaneka Nutrients (Pasadena, TX, USA). Trisodium glycyrrhizinate hydrate was purchased from Tokyo Chemical Industry Co. LTD. (Tokyo, Japan). Eicosapentaenoic acid (EPA) was purchased from Phycoil Biotech Korea, Inc. (Seoul, Korea). EPA was used to improve micelle stability because glycyrrhizin alone is not enough to maintain the micelle. In addition, EPA itself reduces the inflammatory response by inhibiting prostaglandin synthesis. To produce a uniform nano-emulsion (Qmicelle) (Fig. 1A), the following pretreatment is essential. Coenzyme $Q_{10}$, EPA, and trisodium glycyrrhizinate hydrate (at a concentration of $1 \mathrm{mg} / \mathrm{mL}$ each) were dispersed in hot water.
Table 1. Quantification analysis of the nano-emulsion by high performance liquid chromatography

\begin{tabular}{lccc}
\hline Component & $\begin{array}{c}\text { Initial con- } \\
\text { centration, } \\
\mathrm{mg} / \mathrm{mL}\end{array}$ & $\begin{array}{c}\text { Final con- } \\
\text { centration, } \\
\mathrm{mg} / \mathrm{mL}\end{array}$ & $\begin{array}{c}\text { Proportion } \\
\text { of compo- } \\
\text { nent, \% }\end{array}$ \\
\hline EPA & 1.0 & 0.24 & 24 \\
Coenzyme $\mathrm{Q}_{10}$ & 1.0 & 1.0 & 100 \\
Glycyrrhizinate & 1.0 & 0.6 & 60 \\
\hline
\end{tabular}

EPA, eicosapentaenoic acid.

The mixture was pre-homogenized at 10,000 rpm with a homogenizer (Multi-Purpose Homogenizer, YSTRAL, Ballrechten-Dottingen, Germany) until a homogeneous consistency was obtained. An APV2000 microfluidizer processor (SPX Flow, Leeds, UK) was used to produce nano-emulsions (Qmicelle). It has a reservoir capacity of $1,500 \mathrm{~mL}$ and can be operated at pressures of up to 2,000 bars. The prepared mixture at $60^{\circ} \mathrm{C}$ was poured into the fluidizer and Qmicelle was obtained after 10 cycles at a pressure of 1,200 bars. Each component under EPA, coenzyme $\mathrm{Q}_{10}$ and trisodium glycyrrhizinate hydrate, showed single peaks at retention times of 6.0, 6.6, and 15.9 minutes, respectively (Fig. 1B), and their concentrations were $0.24,1.0$ and $0.6 \mathrm{mg} / \mathrm{mL}$ (Table 1). We detected homogeneity and size distribution by dynamic light scattering (DLS), and conformed that sizes of the Qmicelles were uniform and distributed in a narrow range around $100 \mathrm{~nm}$ (Fig. 1C).

\section{Animals and drugs}

All experimental procedures were reviewed and approved by the animal care and use committee of The Catholic University of Korea (CUMC-2018-0038-03). All the protocols in the study were conducted in strict accordance with their ethical guidelines for animal research. Sprague-Dawley rats (Charles River Technology, Seoul, Korea) with a starting weight of 220 to $230 \mathrm{~g}$ were kept in cages (Nalge Co., Rochester, NY, USA) with controlled temperature, humidity, and light in the animal care facility at the Catholic University of Korea. The rats were fed a low-salt diet (0.05\% sodium chloride, Research Diets, New Brunswick, NJ, USA) daily. TAC (Prograft, Astellas Pharma, Ibaraki, Japan) was dissolved in olive oil (Sigma-Aldrich, St. Louis, MO, USA), and blended to a final concentration of $1.5 \mathrm{mg} / \mathrm{mL}$. $\mathrm{CoQ}_{10}$ (Chong 




A

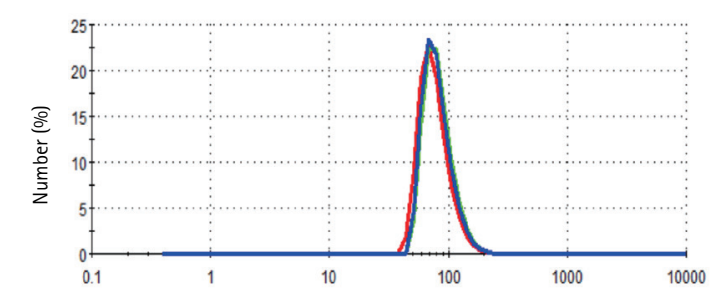

C — Record 1: KGH005 1 Record 2: KGH005 2 Record 3: KGH005 3

Kun Dang Pharm, Seoul, Korea) was diluted in olive oil $\left(\mathrm{CoQ}_{10}-\mathrm{L}\right)$ or drinking water $\left(\mathrm{CoQ}_{10}-\mathrm{W}\right)$ to a final concentration of $20 \mathrm{mg} / \mathrm{kg}$.

\section{Experimental design}

The rats were randomly divided into four groups $(\mathrm{n}=9$ / group). The rats in the vehicle ( $\mathrm{VH})$ group received 0.3 $\mathrm{mL}$ olive oil once a day subcutaneously. The rats in the $\mathrm{TAC}, \mathrm{TAC}+\mathrm{CoQ}_{10}-\mathrm{L}$ and $\mathrm{TAC}+\mathrm{CoQ}_{10}-\mathrm{W}$ groups were treated with TAC $(1.5 \mathrm{mg} / \mathrm{kg})$ subcutaneously daily for 4 weeks. The $\mathrm{TAC}+\mathrm{CoQ}_{10}-\mathrm{L}$ and $\mathrm{TAC}+\mathrm{CoQ}_{10}-\mathrm{W}$ groups were co-treated with $\mathrm{CoQ}_{10}-\mathrm{L}$ or $\mathrm{CoQ}_{10}-\mathrm{W}(20 \mathrm{mg} / \mathrm{kg})$, respectively, orally once a day. We decided the route of administration and concentrations of TAC and $\mathrm{CoQ}_{10}$ based on previous studies [14,15].

\section{Pancreas preservation}

Surgical instruments are sterilized before use. Following abdominal incision, phosphate-buffered saline (PBS) was used for in vivo perfusion via the abdominal aorta. After ensuring that blood was completely removed from the organs, part of the pancreas was removed for further
Figure 1. The microstructure of coenzyme $\mathrm{Q}_{10}\left(\mathrm{Co}_{10}\right)-\mathrm{W}$. (A) Glycyrrhizin-carnitine mixed layer $\mathrm{CoQ}_{10}$ micelle preparation based on acyltransferases. (B) High performance liquid chromatography profile for the components (1) eicosapentaenoic acid (EPA), (2) coenzyme $\mathrm{Q}_{10}$, and (3) trisodium glycyrrhizinate. Note the single peaks for each component. (C) Size distribution of the nano-emulsion by dynamic light scattering. Note the uniform size around $100 \mathrm{~nm}$. TAC, tacrolimus; TAC $+\mathrm{CoQ}_{10}-\mathrm{L}$, TAC cotreatment with lipid-soluble coenzyme $\mathrm{Q}_{10} ; \mathrm{TAC}+\mathrm{CoQ}_{10}-\mathrm{W}$, TAC cotreatment with water-soluble coenzyme $\mathrm{Q}_{10}$.

analysis. Then the perfusion solution was changed to periodate-lysine-paraformaldehyde, and perfusion was continued for an additional 5 minutes. The remaining portion of the pancreas was collected and wax-embedded for histological studies.

\section{Basic protocol}

Following administration of the drug, the diet and weight of the rats were closely monitored for 4 weeks. After 4 weeks of treatment, the rats were placed in a metabolic cage for 24 hours to measure water intake and urine volume. For further analysis, blood and tissue samples were collected from anaesthetized rats a day later. The TAC level in whole blood was measured by liquid chromatography-tandem mass spectrometry (LCMS/MS, Abbott Diagnostics, Abbott Park, IL, USA).

\section{Measurement of $\mathrm{CoQ}_{10}$ in plasma and pancreatic tissue}

The concentration of $\mathrm{CoQ}_{10}$ in the plasma and pancreatic tissues was measured by LC-MS/MS analysis. $\mathrm{CoQ}_{10}$ was extracted from the plasma and tissue and quantified 
using LC-MS/MS method reported previously [16], with some modifications. Given that $\mathrm{CoQ}_{10}$ is an endogenous substance, all calibration and quality control samples were prepared in a physiological solution (4\% bovine serum albumin in PBS). Briefly, $100 \mu \mathrm{L}$ aliquots of rat plasma or tissue homogenates treated with $10 \mu \mathrm{L}$ of $\mathrm{CoQ}_{10}$ $(800 \mathrm{ng} / \mathrm{mL}$, as the internal standard) were extracted by liquid-liquid extraction using $1 \mathrm{~mL}$ isopropyl alcohol, followed by LC-MS/MS analysis. The samples were analyzed using a Shimadzu Nexera X2 UPLC (Shimadzu Corporation, Kyoto, Japan) coupled with an LCMS-8050 triple quadruple mass spectrometer (Shimadzu Corporation) with an electrospray ionization interface in the positive ion mode. Chromatographic separation was achieved using a Kinetex $\mathrm{C}_{18}$ column $(2.1 \times 100 \mathrm{~mm}, 2.6$ $\mu \mathrm{m}$; Phenomenex, Seoul, Korea) with a mobile phase consisting of $0.1 \%$ formic acid in isopropyl alcohol and methanol at a flow rate of $0.2 \mathrm{~mL} / \mathrm{min}$. The total run time was 4 minutes per sample. Quantitation was performed using selected reaction monitoring of the transitions at m/z 863.35 > 197.15 (for $\mathrm{CoQ}_{10}$ ) and m/z 794.35 > 197.15 (for the internal standard). The calibration curves were linear $(r \geq 0.995)$ from 20 to $10,000 \mathrm{ng} / \mathrm{mL}$. The within- and between-batch precision and accuracy were within the acceptable limits of $\pm 15 \%$.

\section{Intraperitoneal glucose tolerance test}

Rats were fasted for 1 day following treatment with the drugs for 4 weeks before the intraperitoneal glucose tolerance test (IPGTT) was conducted. The rats were injected with $50 \%$ dextrose ( $1.5 \mathrm{~g} / \mathrm{kg}$ ), and blood glucose concentration was measured at $30,60,90$, and 120 minutes using a glucose analyzer (Accu-Check, Roche Diagnostics, Basel, Switzerland). Thereafter, based on the IPGT'T values, trapezoidal estimation was obtained, and the area under the curve of glucose (AUCg) was calculated.

\section{Glucose-stimulated insulin secretion assay}

After treating male Sprague-Dawley rats (250 to $300 \mathrm{~g}$ ) with the drugs according to the in vivo experimental design, pancreatic islets were isolated using collagenase digestion as described previously [17]. The islets were incubated in Roswell Park Memorial Institute (RPMI) 1640 medium containing 10\% FBS and $100 \mathrm{U} / \mathrm{mL}$ penicillin at $37^{\circ} \mathrm{C}$ for 24 hours. The next day, groups of 30 islets were washed with Krebs-Ringer Modified Buffer (KRB; $130 \mathrm{mmol} / \mathrm{L}$ sodium chloride [NaCl], $3.6 \mathrm{mmol} / \mathrm{L}$ potassium chloride [KCl], $1.5 \mathrm{mmol} / \mathrm{L}$ calcium chloride $\left[\mathrm{CaCl}_{2}\right], 0.5 \mathrm{mmol} / \mathrm{L}$ magnesium sulfate $\left[\mathrm{MgSO}_{4}\right], 0.5$ $\mathrm{mmol} / \mathrm{L}$ potassium dihydrogen phosphate $\left[\mathrm{KH}^{2} \mathrm{PO}\right]$, 2.0 $\mathrm{mmol} / \mathrm{L}$ sodium bicarbonate $\left[\mathrm{NaHCO}_{3}\right]$, and $10 \mathrm{mmol} / \mathrm{L}$ 2-[4-(2-hydroxyethyl) piperazin-1-yl] ethanesulfonic acid [HEPES]) and $2.8 \mathrm{mM}$ glucose (basal) was added. After washing with $\mathrm{KRB}$, the islets were incubated in KRB containing $16.7 \mathrm{mM}$ glucose for 1 hour. The supernatant was collected and the insulin level was measured using a sandwich enzyme-linked immunosorbent assay (ELISA) (Millipore Corp., St. Charles, MO, USA).

\section{Immunohistochemistry}

All the immunohistochemistry (IHC) procedures were performed as described previously [18]. The primary antibodies used for IHC were as follows: anti-insulin (I2018, Sigma-Aldrich; 18-0067, Invitrogen, Carlsbad, CA, USA), anti-8-hydroxy-2'-deoxyguanosine (8-OHdG; JaICA, Shizuoka, Japan), and anti-4-hydroxy-2-hexenal (4-HHE, JaICA, Shizuoka, Japan). 4-m samples were incubated with the antibodies for 12 hours at $4^{\circ} \mathrm{C}$. A minimum of 20 fields per section was assessed using a color image analyzer (TDI Scope Eye version 3.6 for Windows, JN OpTIC Co. Ltd., Seoul, Korea). Briefly, images captured during insulin immunohistochemistry were quantified using the polygon program by measuring the pancreas area that was positively stained for insulin, except for vacuoles, when viewed under $\times 400$ magnification. The measurement of 4-HHE expression was similar to that of insulin, and expressed as percentage of 4-HHE positive area in the islet. The 8-OHdG expression was quantified by counting the number of positive cells per field. Histopathologic analysis was performed on randomly selected fields of the pancreas sectioned by a pathologist blinded to the identity of the treatment groups.

\section{Serum 8-OHdG detection}

All procedures were carried out strictly according to the ELISA kit protocol (Cell Biolabs, San Diego, CA, USA).

\section{In situ TUNEL assay}

Terminal deoxynucleotide transferase-mediated dUTP nick-end labeling (TUNEL) staining was performed using the in situ Apoptosis Detection Kit (Millipore, Bill- 
erica, MA, USA) as per manufacturer's instructions. In each tissue section, positive cells were analyzed in 20 randomly selected areas. The positive cells or areas were then quantified at $\times 400$ magnification, and the data were analyzed with a color image analyzer (TDI Scope Eye version 3.6 for Windows).

\section{Transmission electron microscopy}

Pancreatic tissues were fixed in $2.5 \%$ glutaraldehyde (diluted in $0.1 \mathrm{M}$ phosphate buffer), post-fixed with 1\% Osmium (VIII) oxide $\left(\mathrm{OsO}_{4}\right)$ and then embedded in Epon 812. Ultrathin sections were prepared using the embedded tissues, and the sections were stained with uranyl acetate/lead citrate. A JEM-120oEX transmission election microscope (JEOL, Tokyo, Japan) was used for photography, and 20 randomly selected sites were scanned at $\times 5,000$ magnification. We counted insulin granule number and measured mitochondrial area in the scanned areas using an image analyzer (TDI Scope Eye version 3.6).

\section{In vitro cell culture}

The INS-1 rat insulinoma cell line was grown in conditioned RPMI-1640 medium supplemented with $10 \mathrm{nM}$ HEPES, $10 \%$ fetal bovine serum, $2 \mathrm{mM}$ L-glutamine, 1 $\mathrm{mM}$ sodium pyruvate, $50 \mathrm{mM}$ 2-mercaptoethanol (all from Sigma-Aldrich), $100 \mathrm{IU} / \mathrm{mL}$ penicillin, and $100 \mathrm{mg} /$ $\mathrm{mL}$ streptomycin (both from Wisent Bio, Saint-Bruno, QC, Canada) in a humidified atmosphere containing 5\% $\mathrm{CO}_{2}$. Cells were plated in culture plates.

\section{Cell viability}

A cell counting kit-8 (CCK-8, CKo4; Dojindo Molecular Technologies, Rockville, MD, USA) assay kit was used for analyzing cell viability. After plating the INS-1 cells for 1 day, the cells were treated with TAC $(40 \mathrm{mg} / \mathrm{mL})$, and same dose of either $\mathrm{CoQ}_{10}-\mathrm{L}$ (0.1 pg/mL, $1 \mathrm{pg} / \mathrm{mL}, 10 \mathrm{pg} /$ $\mathrm{mL}, 1 \mathrm{ng} / \mathrm{mL}, 10 \mathrm{ng} / \mathrm{mL}, 100 \mathrm{ng} / \mathrm{mL}$, and $1 \mu \mathrm{g} / \mathrm{mL}$ ) diluted with dimethyl sulfoxide (DMSO) or $\mathrm{CoQ}_{10}-\mathrm{W}(0.1 \mathrm{pg} / \mathrm{mL}$, $1 \mathrm{pg} / \mathrm{mL}, 10 \mathrm{pg} / \mathrm{mL}, 1 \mathrm{ng} / \mathrm{mL}, 10 \mathrm{ng} / \mathrm{mL}, 100 \mathrm{ng} / \mathrm{mL}$, and $1 \mu \mathrm{g} / \mathrm{mL}$ ) diluted with water for 12 hours. According to the manufacture's protocol, CCK-8 or propidium iodide (PI; 556463, BD Biosciences, San Jose, CA, USA) solution was added for 2 hours. Following CCK- 8 treatment, the absorbance was measured at $450 \mathrm{~nm}$ using a Versa Max ELISA Reader (Molecular Devices, Sunnyvale, CA, USA).

\section{Flow cytometry}

To assess reactive oxygen species (ROS) production, we performed flow cytometry. INS-1 cells were plated and pre-incubated in an incubator at $37^{\circ} \mathrm{C}$ for 24 hours. After 24 hours, the culture medium was changed to serum-free medium containing TAC $(40 \mathrm{mg} / \mathrm{mL})$, TAC $(40 \mathrm{mg} / \mathrm{mL})+$ $\mathrm{CoQ}_{10}-\mathrm{L}(10 \mathrm{ng} / \mathrm{mL})$ or $\mathrm{TAC}+\mathrm{CoQ}_{10}-\mathrm{W}(10 \mathrm{ng} / \mathrm{mL})$. The method followed has been described previously [19].

\section{Statistical analysis}

The data are expressed as mean \pm standard error (SE) of at least three independent experiments. Multiple comparisons between different groups were carried out by oneway analysis of variance with Bonferroni's post hoc test using IBM SPSS Statistics version 24 (IBM, Armonk, NY, USA). Results with $p<0.05$ were considered statistically significant.

\section{RESULTS}

\section{Comparison of the basic parameters of $\mathrm{CoQ}_{10}-\mathrm{L}$ and $\mathrm{CoQ}_{10}-\mathrm{W}$ in TAC-induced DM rats}

TAC treatment for 4 weeks significantly reduced the body weight compared to $\mathrm{VH}$ treatment $(48 \pm 6 \mathrm{~g}$ vs. 67 $\pm 3 \mathrm{~g}, \mathrm{p}<0.05)$. These changes were restored in the TAC $+\mathrm{CoQ}_{10}-\mathrm{L}$ and $\mathrm{TAC}+\mathrm{CoQ}_{10}-\mathrm{W}$ groups $(48 \pm 6 \mathrm{~g}$ vs. $62 \pm$ $1 \mathrm{~g}$ and $65 \pm 2 \mathrm{~g}, \mathrm{p}<0.05)$. Water intake was increased in the TAC group compared with the $\mathrm{VH}$ group $(49 \pm 6 \mathrm{~mL}$ vs. $30 \pm 2 \mathrm{~mL}, p<0.05)$. In the $\mathrm{TAC}+\mathrm{CoQ}_{10}-\mathrm{L}$ and TAC $+\mathrm{CoQ}_{10}-\mathrm{W}$ groups, water intake was lower than in the TAC group $(35 \pm 1 \mathrm{~mL}$ and $39 \pm 4 \mathrm{~mL}$ vs. $49 \pm 6 \mathrm{~mL}, p<$ 0.05). The concentration of TAC in whole blood was not affected by $\mathrm{CoQ}_{10}-\mathrm{L}$ or $\mathrm{CoQ}_{10}-\mathrm{W}$ treatment $(9.4 \pm 4 \mathrm{ng} / \mathrm{mL}$ vs. $9.3 \pm 2$ or $9.3 \pm 3 \mathrm{ng} / \mathrm{mL}, p>0.05)$.

\section{Comparison of the plasma and pancreas $\mathrm{CoQ}_{10}$ levels with $\operatorname{CoQ}_{10}-L$ and $\mathrm{CoQ}_{10}-\mathrm{W}$ treatments of TAC-induced DM rats}

Plasma $\mathrm{CoQ}_{10}$ levels in the $\mathrm{VH}$ and TAC groups were $39 \pm 7$ and $25 \pm 8 \mathrm{ng} / \mathrm{mL}$, respectively. The plasma $\mathrm{CoQ}_{10}$ level (Fig. 2A) was significantly higher in the TAC + $\mathrm{CoQ}_{10}-\mathrm{W}$ group than the $\mathrm{TAC}+\mathrm{CoQ}_{10}-\mathrm{L}$ group $(956 \pm$ $97 \mathrm{ng} / \mathrm{mL}$ vs. $577 \pm 88 \mathrm{ng} / \mathrm{mL}, p<0.05)$. The pancreatic $\mathrm{CoQ}_{10}$ level (Fig. 2B) was lower in the TAC group than in the VH group $(59 \pm 8 \mathrm{ng} / \mathrm{mL}$ vs. $103 \pm 26 \mathrm{ng} / \mathrm{mL}, p$ 


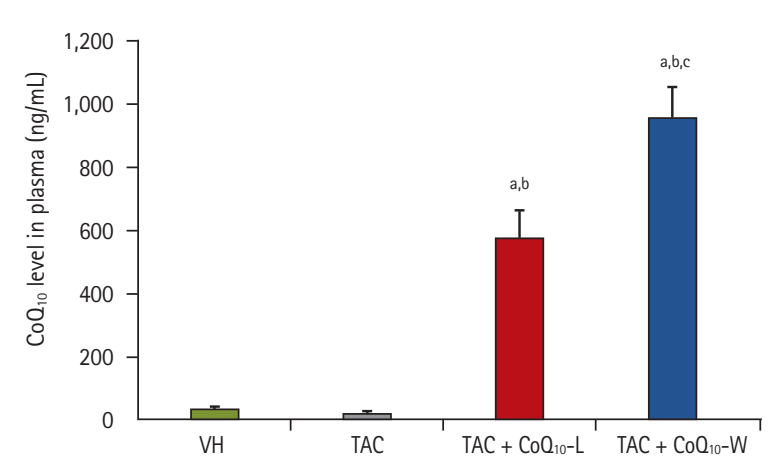

A

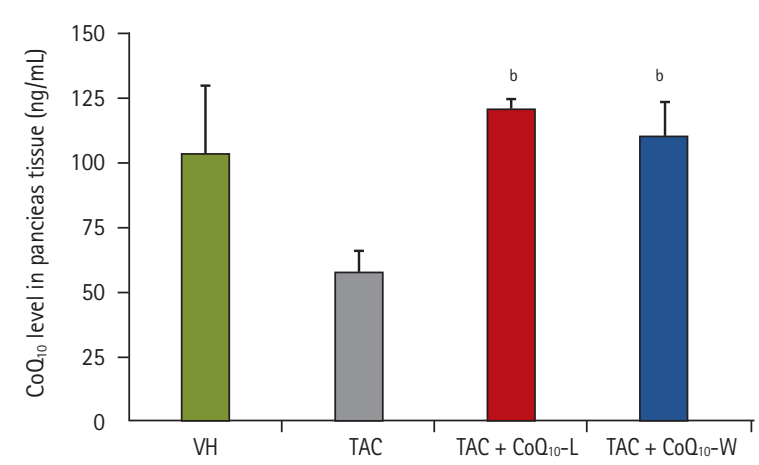

B

Figure 2. Comparison of plasma and pancrea coenzyme $\mathrm{Q}_{10}\left(\mathrm{CoQ}_{10}\right)$ levels in $\mathrm{CoQ}_{10}-\mathrm{L}$ and $\mathrm{CoQ}_{10}-\mathrm{W}$ in tacrolimus (TAC)-induced diabetes mellitus rats. (A) Concentrations of $\mathrm{CoQ}_{10}$ in plasma and (B) pancreas tissue were measured by liquid chromatography-tandem mass spectrometry analysis. Data are presented as mean \pm standard error $(n=9)$. One-way analysis of variance was used to analyze the data. VH, vehicle; TAC + CoQ10-L, TAC cotreatment with lipid-soluble coenzyme $\mathrm{Q}_{10} ; \mathrm{TAC}+\mathrm{CoQ}{ }_{10}-\mathrm{W}, \mathrm{TAC}$ cotreatment with water-soluble coenzyme $\mathrm{Q}_{10} \cdot{ }^{\mathrm{a}} \mathrm{p}<0.05$ vs. VH. ${ }^{\mathrm{b}} \mathrm{p}<0.05$ vs. TAC. ${ }^{\mathrm{c}} \mathrm{p}<0.05$ vs. TAC $+\mathrm{CoQ}_{10}-\mathrm{L}$.

$<$ 0.05). Treatment with either TAC $+\mathrm{CoQ}_{10}-\mathrm{L}$ or TAC $+\mathrm{CoQ}_{10}-\mathrm{W}$ increased pancreatic $\mathrm{CoQ}_{10}$ levels compared with the TAC only group $(121 \pm 4 \mathrm{ng} / \mathrm{mL}$ and $110 \pm 14$ $\mathrm{ng} / \mathrm{mL}$ vs. $59 \pm 8 \mathrm{ng} / \mathrm{mL}, p<0.05)$. However, there was no significant difference between the two groups.

\section{Comparison of blood glucose levels with $\mathrm{Co}_{10}-\mathrm{L}$ and $C_{0} Q_{10}-W$ treatments of TAC-induced DM rats}

After the 4-week drug-treatment regimen, we performed a IPGTT to evaluate the changes in blood glucose level. Thirty minutes after injecting 50\% dextrose, blood glucose was significantly higher in the TAC group than the VH group $(434 \pm 9 \mathrm{ng} / \mathrm{mL}$ vs. $322 \pm 16 \mathrm{mg} / \mathrm{dL}, p<$ 0.05). Unlike TAC $+\mathrm{CoQ}_{10}-\mathrm{L}$ treatment $(430 \pm 6 \mathrm{mg} / \mathrm{dL})$, $\mathrm{TAC}+\mathrm{CoQ}_{10}-\mathrm{W}$ treatment $(379 \pm 14 \mathrm{mg} / \mathrm{dL})$ decreased the blood glucose level relative to TAC for 120 minutes (Fig. 3A). The increase in AUCg values detected by IPGTT demonstrated that DM was successfully induced by TAC $(273 \pm 19 \mathrm{mg} / \mathrm{dL} / \mathrm{min}$ vs. $162 \pm 18 \mathrm{mg} / \mathrm{dL} / \mathrm{min}, p<$ 0.05). The $\mathrm{TAC}+\mathrm{CoQ}_{10}$-L group had no significant difference in AUCg compared with the TAC group (241 \pm 23 vs. $273 \pm 19 \mathrm{mg} / \mathrm{dL} / \mathrm{min}, p>0.05)$. The decrease was markedly higher in the TAC $+\mathrm{CoQ}_{10}-\mathrm{W}$ group $(170 \pm 12$ $\mathrm{mg} / \mathrm{dL} / \mathrm{min}, \boldsymbol{p}<0.05$ ) (Fig. 3B).

\section{Comparison of insulin secretion with $\operatorname{CoQ}_{10}-\mathrm{L}$ and $\mathrm{CoQ}_{10}-\mathrm{W}$ treatments of TAC-induced DM rats} Insulin secretion was significantly reduced by TAC treat- ment compared to $\mathrm{VH}(11 \pm 0.6 \mathrm{ng} / \mathrm{mL}$ vs. $25 \pm 1 \mathrm{ng} / \mathrm{mL}, p<$ 0.05) (Fig. 4). $\mathrm{CoQ}_{10}-\mathrm{W}$ increased insulin secretion $(15 \pm 0.5$ $\mathrm{ng} / \mathrm{mL}, p<0.05)$ unlike $\mathrm{CoQ}_{10}-\mathrm{L}(11 \pm 0.2 \mathrm{ng} / \mathrm{mL}, p>0.05)$.

\section{Comparison of islet size with $\mathrm{CoQ}_{10}-\mathrm{L}$ and $\mathrm{CoQ}_{10}-\mathrm{W}$ treatments of TAC-induced DM rats}

Immunohistochemical staining for insulin showed that the islet sizes in the TAC group and $\mathrm{TAC}+\mathrm{CoQ}_{10}-\mathrm{L}$ group were lower than that in the $\mathrm{VH}$ group $(8 \pm 2$ and $9 \pm 1$ vs. $\left.16 \pm 2 \mu \mathrm{m}^{2} \times 10^{3}, p<0.05\right)$. However, the islet size in the TAC + CoQ10-W group $\left(14 \pm 1 \mu \mathrm{m}^{2} \times 10^{3}\right)$ was increased compared with the TAC and the TAC $+\mathrm{CoQ}_{10}-\mathrm{L}$ groups $(p<0.05)$ (Fig. 5).

\section{Comparison of oxidative stress with $\mathrm{CoQ}_{10}-\mathrm{L}$ and $\mathrm{CoQ}_{10}-\mathrm{W}$ treatments of TAC-induced DM rats}

Immunohistochemical staining for the oxidative stress markers 8-OHdG (Fig. 6A and 6B), and 4-HHE (Fig. 6C and 6D), and ELISA for serum 8-OHdG (Fig. 6E) were used to identify the anti-oxidative effects. The number of 8-OHdG-positive cells was significantly increased in the TAC group compared with the VH group $(140 \pm 10$ per field vs. $3 \pm 1$ per field, $p<0.05) \cdot \mathrm{CoQ}_{10}-\mathrm{W}(83 \pm 6$ per field $)$ significantly decreased the expression of 8-OHdG unlike $\mathrm{CoQ}_{10}-\mathrm{L}(138 \pm 6$ per field). The expression of 4 -HHE was significantly higher in the TAC group than in the $\mathrm{VH}$ group $(15 \% \pm 1 \%$ vs. $0.3 \% \pm 1 \%, p<0.05)$. $\mathrm{CoQ}_{10}-\mathrm{W}(6 \% \pm$ $1 \%)$ significantly decreased the expression of 4 - $\mathrm{HHE}(p<$ 

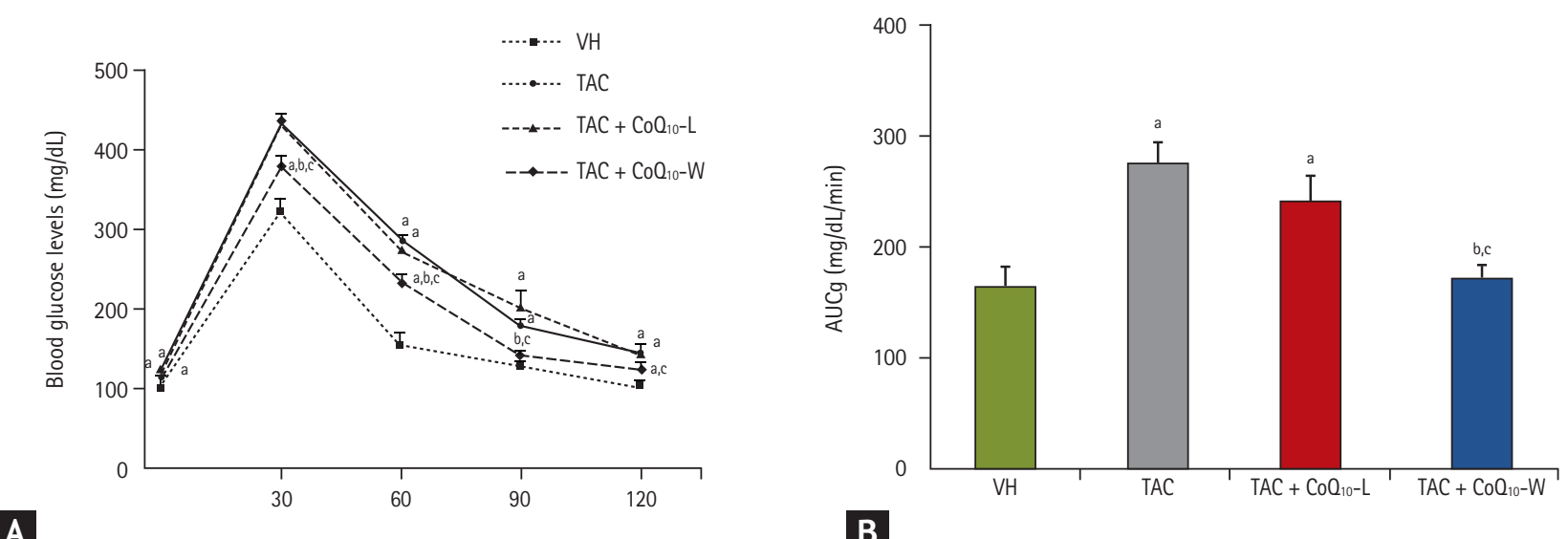

B

Figure 3. Comparison of blood glucose with coenzyme $\mathrm{Q}_{10}\left(\mathrm{CoQ}_{10}\right)-\mathrm{L}$ and $\mathrm{CoQ}_{10}-\mathrm{W}$ treatments of tacrolimus (TAC)-induced diabetes mellitus rats. (A) Blood glucose levels were measured using intraperitoneal glucose tolerance test (IPGTT), and the (B) AUCg was calculated from IPGTT values. Data are presented as mean \pm standard error $(n=9)$. Scale bar $=100 \mu \mathrm{m}$. One-way analysis of variance was used to analyze the data. $\mathrm{VH}$, vehicle; TAC $+\mathrm{CoQ}_{10}-\mathrm{L}$, TAC cotreatment with lipid-soluble coenzyme $\mathrm{Q}_{10} ; \mathrm{TAC}+\mathrm{CoQ}_{10}-\mathrm{W}$, TAC cotreatment with water-soluble coenzyme Q10; AUCg, area under the curve of glucose. ${ }^{\mathrm{a}} \mathrm{p}<0.05 \mathrm{vs}$. VH. ${ }^{b} p<0.05$ vs. TAC. ${ }^{c} p<0.05$ vs. TAC $+\mathrm{CoQ}_{10}-\mathrm{L}$.

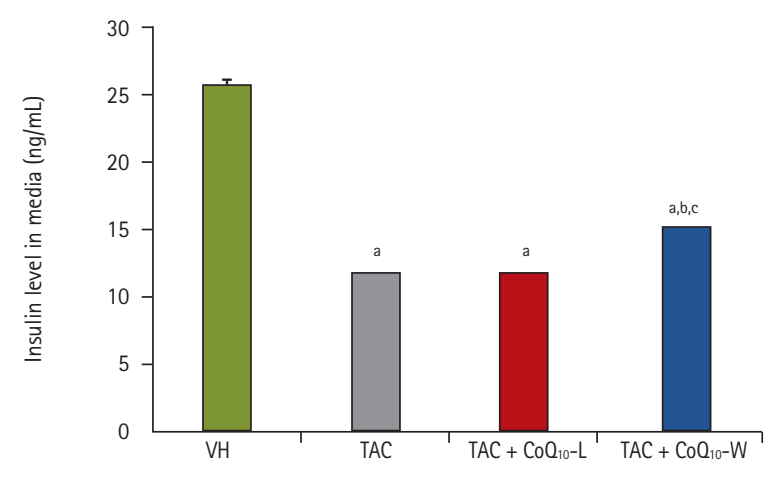

Figure 4. Comparison of insulin secretion after glucose-stimulated insulin secretion (GSIS) with coenzyme $\mathrm{Q}_{10}$ $\left(\mathrm{CoQ}_{10}\right)-\mathrm{L}$ and $\mathrm{CoQ}_{10}-\mathrm{W}$ treatments of tacrolimus (TAC)-induced diabetes mellitus rats. enzyme-linked immunosorbent assay was used to measure insulin secretion after GSIS. Data are presented as mean \pm standard error $(n=9)$. Scale $\mathrm{bar}=100 \mu \mathrm{m}$. One-way analysis of variance was used to analyze the data. $\mathrm{VH}$, vehicle; TAC $+\mathrm{CoQ}_{10}-\mathrm{L}$, TAC cotreatment with lipid-soluble coenzyme $\mathrm{Q}_{10}$; TAC $+\mathrm{CoQ}_{10}-\mathrm{W}$, TAC cotreatment with water-soluble coenzyme $\mathrm{Q}_{10} \cdot{ }^{\mathrm{a}} \mathrm{p}<0.05$ vs. VH. ${ }^{b} p<0.05$ vs. TAC. ${ }^{c} p<0.05$ vs. TAC + CoQ10-L.

0.05) while $\mathrm{CoQ}_{10}-\mathrm{L}(14 \% \pm 1 \%)$ did not. Similar changes were observed in serum 8-OHdG level (Fig. 6E).

\section{Comparison of apoptosis in pancreatic islets with $\mathrm{CoQ}_{10}-\mathrm{L}$ and $\mathrm{CoQ}_{10}-\mathrm{W}$ treatments of TAC-induced DM rats}

Four weeks of TAC treatment also induced apoptosis in the pancreas. As shown in Fig. 7, the number of TUNEL-positive cells was significantly higher in the TAC group than in the VH group $(2.4 \pm 0.3$ cells per islet vs. $\mathrm{O} \pm \mathrm{o}$ cells per islet, $p<0.05) \cdot \mathrm{CoQ}_{10}-\mathrm{W}$ decreased TUNEL-positive cells compared with TAC (0.2 \pm 0.2 cells per islet vs. $2.4 \pm 0.3$ cells per islet, $p<0.05$ ), while $\mathrm{CoQ}_{10}-\mathrm{L}$ (1.8 0.2 cells per islet) did not (Fig. 7).

\section{Comparison of the mitochondrial area and insulin granule with $\mathrm{CoQ}_{10}-\mathrm{L}$ and $\mathrm{CoQ}_{10}-\mathrm{W}$ treatments of TAC-induced DM rats}

Electron microscopy was used to evaluate the changes in the mitochondrial area and insulin granule number. The average mitochondrial area was significantly lower in the TAC and TAC $+\mathrm{CoQ}_{10}-\mathrm{L}$ groups than in the $\mathrm{VH}$ group $(0.05 \pm 0.006$ and $0.08 \pm 0.08$ vs. $0.4 \pm 0.03$ per field, $p<0.05)$. However, the numbers were significantly $(p<$ 0.05 ) higher in the TAC+CoQ ${ }_{10}-\mathrm{W}$ group ( $0.2 \pm 0.02$ per field) (Fig. 8A and 8C). Changes in insulin granule numbers were similar to the changes in mitochondrial area (Fig. 8A and 8B). 


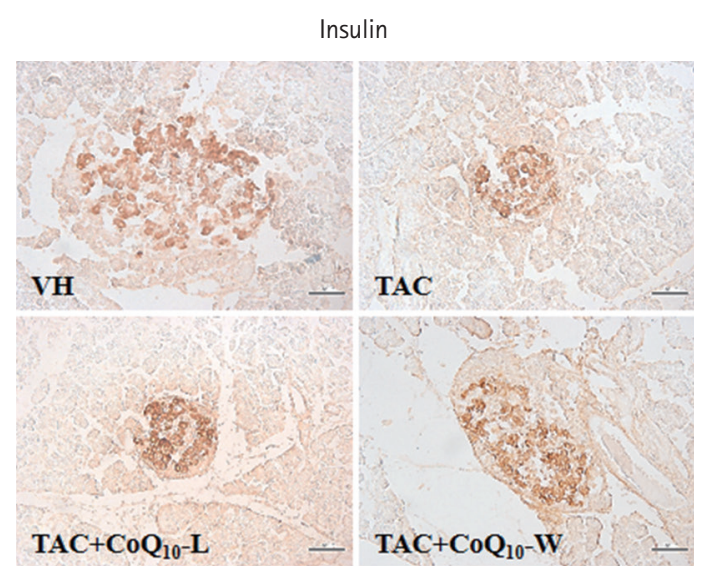

$\mathrm{TAC}+\mathrm{CoQ}_{10}-\mathrm{L}$
$\mathrm{TAC}+\mathrm{CoQ}_{10}-\mathbf{W}$

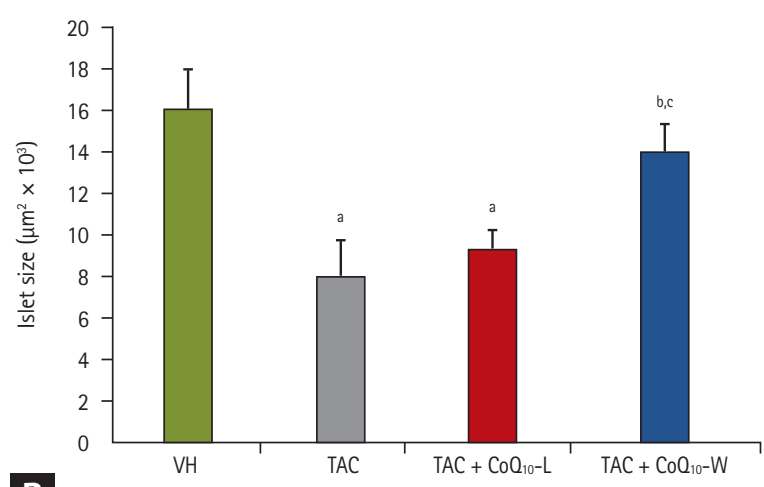

B

Figure 5. Comparison of islet size with coenzyme $\mathrm{Q}_{10}\left(\mathrm{CoQ}_{10}\right)-\mathrm{L}$ and $\mathrm{CoQ}_{10}-\mathrm{W}$ treatments of tacrolimus (TAC)-induced diabetes mellitus rats using immunohistochemical analysis in tissues section. (A) Representative images of insulin staining in pancreatic sections. (B) Quantitative analysis of beta cell area. Data are presented as mean \pm standard error $(\mathrm{n}=9)$. Scale bar $=100 \mu \mathrm{m}$. Oneway analysis of variance was used to analyze the data. $\mathrm{VH}$, vehicle; $\mathrm{TAC}+\mathrm{CoQ}_{10}-\mathrm{L}$, TAC cotreatment with lipid-soluble coenzyme $\mathrm{Q}_{10}$; TAC $+\mathrm{CoQ}_{10}-\mathrm{W}$, TAC cotreatment with water-soluble coenzyme $\mathrm{Q}_{10} \cdot{ }^{\mathrm{a}} \mathrm{p}<0.05 \mathrm{vs} . \mathrm{VH} .{ }^{\mathrm{b}} \mathrm{p}<0.05 \mathrm{vs}$. TAC. ${ }^{\mathrm{c}} \mathrm{p}<0.05 \mathrm{vs}$. TAC + $\mathrm{CoQ}_{10}-\mathrm{L}$.

\section{Comparison of cell viability with $\mathrm{CoQ}_{10}-\mathrm{L}$ and $\mathrm{CoQ}_{10}-\mathrm{W}$ treatments of TAC-induced INS cell injury} We demonstrated the protective effect of $\mathrm{CoQ}_{10}-\mathrm{L}$ and $\mathrm{CoQ}_{10}-\mathrm{W}$ against cell injury during TAC treatment in INS-1, a pancreatic beta cell line. At the different doses tested, both $\mathrm{TAC}+\mathrm{CoQ}_{10}-\mathrm{L}$ and $\mathrm{TAC}+\mathrm{CoQ}_{10}-\mathrm{W}$ increased cell viability by approximately 2.8 -fold compared to TAC $(p<0.05)$. However, there were no differences between the tested doses of TAC $+\mathrm{CoQ}_{10}-\mathrm{L}$ and $\mathrm{TAC}+\mathrm{CoQ}_{10}-\mathrm{W}(p>0.05)$ (Fig. 9).

\section{Comparison of ROS production with $\mathrm{Co}_{10}-\mathrm{L}$ and $\mathrm{CoQ}_{10}-W$ treatments of TAC-induced INS cell injury}

To compare the protective effect of $\mathrm{CoQ}_{10}-\mathrm{L}$ and $\mathrm{CoQ}_{10}$-W on oxidative stress, we performed flow cytometry using INS-1 cells. TAC significantly increased ROS production compared to the $\mathrm{VH}(p<0.05)$. Both $\mathrm{CoQ}_{10}-\mathrm{L}$ and $\mathrm{CoQ}_{10}-\mathrm{W}$ reduced TAC-induced ROS production; though there was no significant difference between the two groups $(p>0.05)$ (Fig. 10).

\section{DISCUSSION}

This study investigated whether $\mathrm{CoQ}_{10}-\mathrm{W}$ provides better protection against TAC-induced pancreatic beta cell dysfunction than conventional $\mathrm{CoQ}_{10}\left(\mathrm{CoQ}_{10}-\mathrm{L}\right)$. The results of our study clearly demonstrate that $\mathrm{CoQ}_{10}-\mathrm{W}$ increases insulin secretion, and thus lowers blood glucose in TAC-induced diabetes. In addition, $\mathrm{CoQ}_{10}-\mathrm{W}$ reduced TAC-induced oxidative stress and apoptosis in the pancreas more than $\mathrm{CoQ}_{10}-\mathrm{L}$. This finding suggests that improving the bioavailability using $\mathrm{CoQ}_{10}-\mathrm{W}$ may overcome the limitations of $\mathrm{CoQ}_{10}-\mathrm{L}$ and render it more effective as an anti-diabetic and anti-oxidative agent.

Until now, several approaches have been used for improving the bioavailability of $\mathrm{CoQ}_{10}[20-23]$ that can be summarized in two ways as follows: One is to increase the dissolution rate of the drug, and the other is to promote absorption of the drug by optimizing the digestion process. We used the latter method of optimizing the digestion process, to improve drug absorption. The $\mathrm{CoQ}_{10}-\mathrm{W}$ used in this study consists of a glycyrrhizin-carnitine mixed layer $\mathrm{CoQ}_{10}$ micelle preparation based on acyltransferases as shown in Fig. 1. This formula improved the absorption of $\mathrm{CoQ}_{10}$ by using the natural extract-glycyrrhizin as the carrier, and the heat of fusion which converts the $\mathrm{CoQ}_{10}$ from hydrophobic to hydrophilic. In addition, this formulation has the advantage of retaining the original chemical structure of $\mathrm{CoQ}_{10}$ and eliminating the formation of toxic substances during the synthesis and conversion processes. The 


\section{$8-\mathrm{OHdG}$}
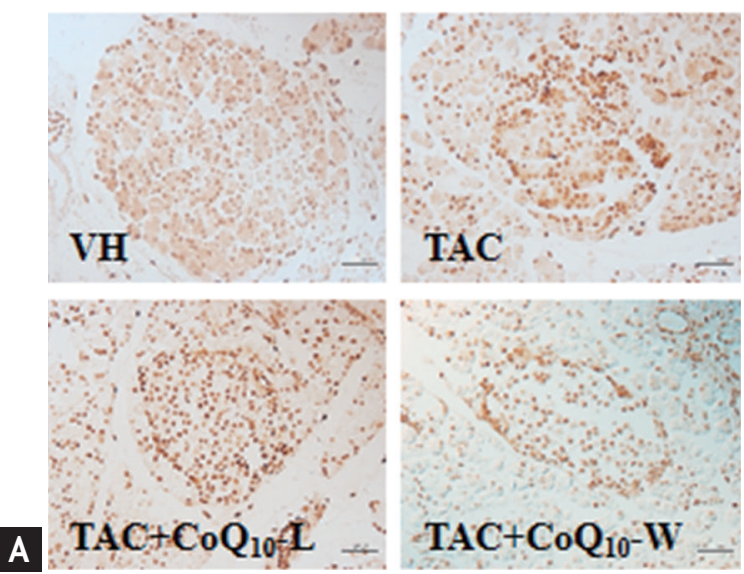

$\mathrm{TAC}+\mathrm{CoQ}_{10}-\mathrm{W}$
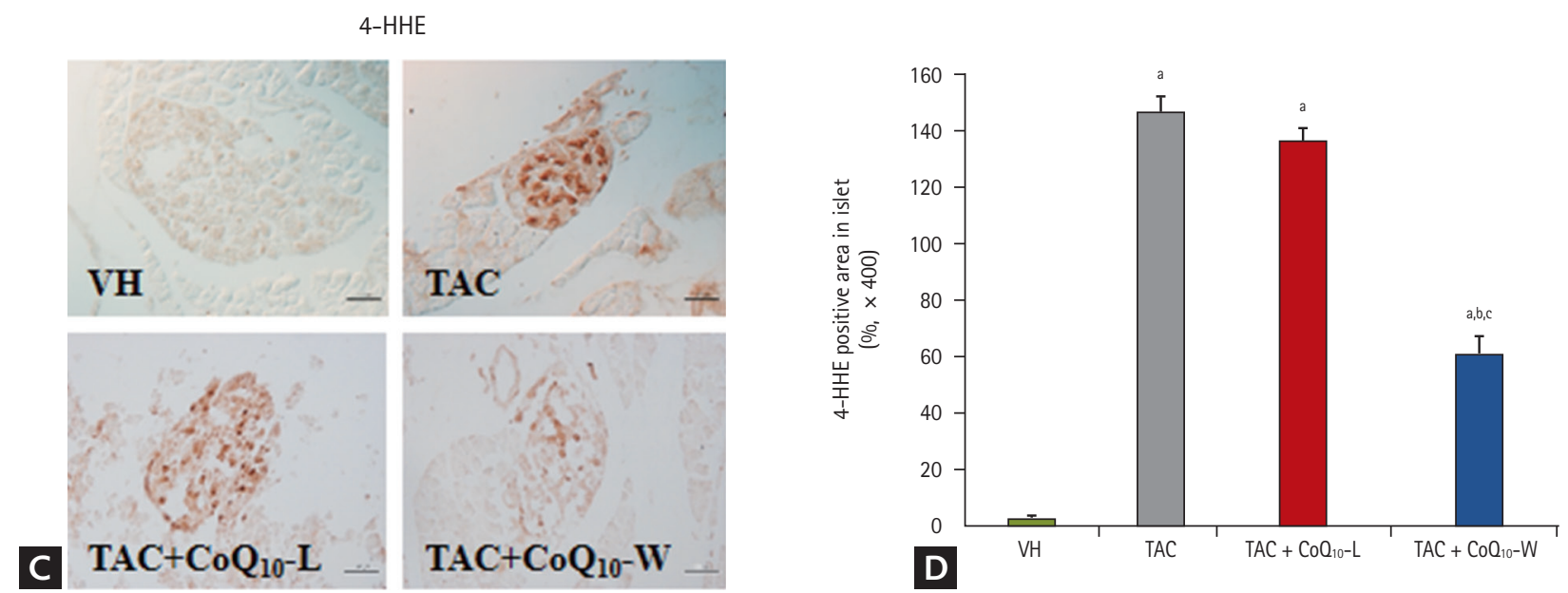

Figure 6. Comparison of oxidative stress with coenzyme $\mathrm{Q}_{10}\left(\mathrm{CoQ}_{10}\right)-\mathrm{L}$ and $\mathrm{Co}_{10}-\mathrm{W}$ treatments of tacrolimus (TAC)-induced diabetes mellitus rats using immunohistochemical analysis in tissues sections. Representative images and quantification of immunohistochemistry for (A, B) 8-hydroxy-2'-deoxyguanosine (8-OHdG) and (C, D) 4-hydroxy-2-hexenal (4-HHE) using rat tissue sections. (E) Representative quantification of 8-OHdG enzyme-linked immunosorbent assay on rat serum. Scale bar $=100 \mu \mathrm{m}$ (all panels). Data are presented as mean \pm standard error $(n=8)$. One-way analysis of variance was used to analyze the data. $\mathrm{VH}$, vehicle; TAC + Co $\mathrm{Q}_{10}-\mathrm{L}$, TAC cotreatment with lipid-soluble coenzyme $\mathrm{Q}_{10} ; \mathrm{TAC}+\mathrm{CoQ}_{10}-\mathrm{W}$, TAC cotreatment with water-soluble coenzyme $\mathrm{Q}_{10}{ }^{a} \mathrm{p} p<0.05$ vs. VH. ${ }^{\mathrm{b}} \mathrm{p}<0.05$ vs. TAC. ${ }^{c} p<0.05$ vs. TAC $+\mathrm{CoQ}_{10}-\mathrm{L}$. 


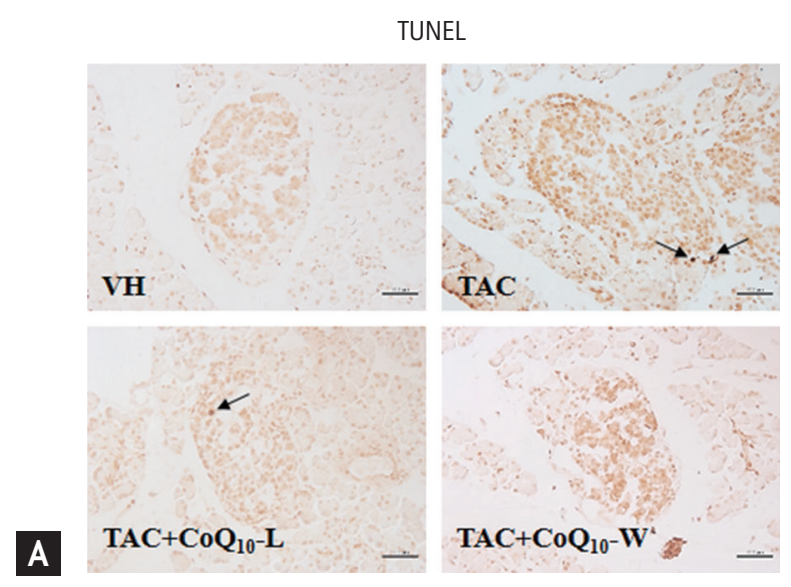

Figure 7. Comparison of apoptosis in pancreatic islets with coenzyme $\mathrm{Q}_{10}\left(\mathrm{CoQ}_{10}\right)-\mathrm{L}$ and $\mathrm{CoQ}_{10}-\mathrm{W}$ treatments of tacrolimus (TAC)-induced diabetes mellitus in rats. Representative (A) images and (B) quantification of TUNEL staining. Arrows indicate TUNEL positive cells. Scale bar $=100 \mu \mathrm{m}$ (all panels). Data are presented as mean \pm standard error $(\mathrm{n}=9)$. One-way analysis of variance was used to analyze the data. $\mathrm{VH}$, vehicle; $\mathrm{TAC}+\mathrm{CoQ}_{10}-\mathrm{L}$, TAC cotreatment with lipid-soluble coenzyme $\mathrm{Q}_{10}$; TAC + $\mathrm{CoQ}_{10}-\mathrm{W}$, TAC cotreatment with water-soluble coenzyme $\mathrm{Q}_{10}$; TUNEL, terminal deoxynucleotide transferase-mediated dUTP nick-end labeling. ${ }^{\mathrm{a}} \mathrm{p}<0.05$ vs. VH. ${ }^{\mathrm{b}} \mathrm{p}<0.05$ vs. TAC. ${ }^{\mathrm{c}} \mathrm{p}<0.05$ vs. TAC $+\mathrm{CoQ}_{10}-\mathrm{L}$.
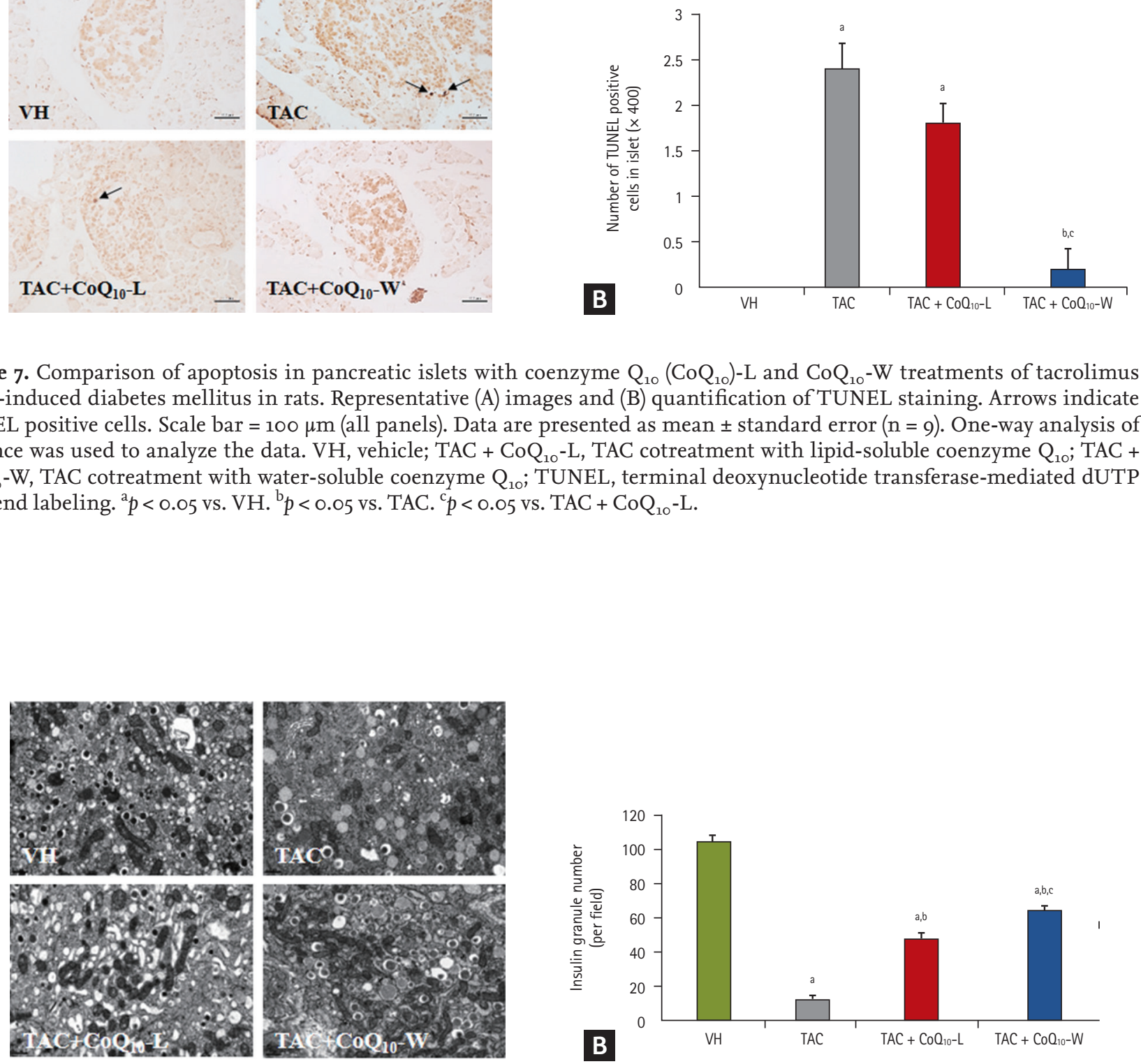

B 


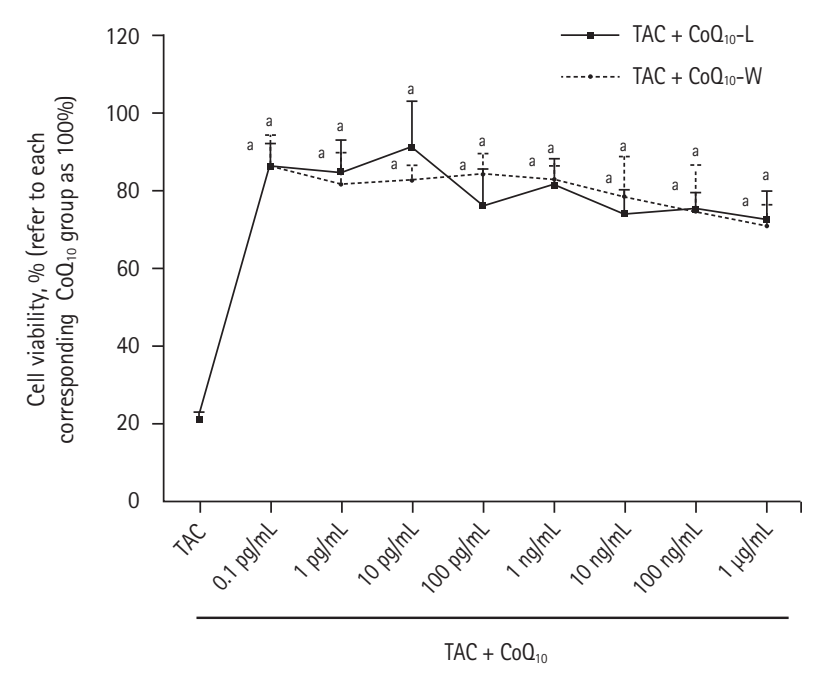

Figure 9. Comparison of cell viability with coenzyme $Q_{10}$ $\left(\mathrm{CoQ}_{10}\right)-\mathrm{L}$ and $\mathrm{CoQ}_{10}-\mathrm{W}$ treatments of tacrolimus (TAC)-induced insulinoma (INS) cell injury. Cell viability was evaluated with a cell counting kit 8 (CCK-8) assay. Data are presented as mean \pm standard error $(n=5)$. One-way analysis of variance was used to analyze the data. TAC $+\mathrm{CoQ}_{10}-\mathrm{L}$, TAC cotreatment with lipid-soluble coenzyme $\mathrm{Q}_{10}$; TAC + $\mathrm{CoQ}_{10}-\mathrm{W}$, TAC cotreatment with water-soluble coenzyme $\mathrm{Q}_{10} \cdot{ }^{\mathrm{a}} \mathrm{p}<0.05$ vs. TAC. composition of $\mathrm{CoQ}_{10}$ in the solution may be affected by high pressure or high temperature during the manufacture of $\mathrm{CoQ}_{10}-\mathrm{W}$. Thus, we confirmed the homogeneity and uniform size of the micelles by high performance liquid chromatography after preparation as shown Fig. 1. With this formulation, we achieved higher plasma $\mathrm{CoQ}_{10}$ levels (1.7 times) than with $\mathrm{CoQ}_{10}-\mathrm{L}$.

We evaluated whether $\mathrm{CoQ}_{10}$-W had improved effects on glucose-lowering and insulin secretion compared to $\mathrm{CoQ}_{10}-\mathrm{L}$ in an experimental model of TAC-induced DM. In this study, we found that $\operatorname{CoQ}_{10}-\mathrm{W}$ significantly reduced TAC-induced hyperglycemia, while $\mathrm{CoQ}_{10}-\mathrm{L}$ did not. In addition, glucose-stimulated insulin secretion (GSIS) revealed that $\mathrm{CoQ}_{10}$-W significantly restored the TAC-induced decrease in insulin secretion, unlike $\mathrm{CoQ}_{10}-\mathrm{L}$. These results suggest that $\mathrm{CoQ}_{10}-\mathrm{W}$ is more effective than $\mathrm{CoQ}_{10}-\mathrm{L}$ at lowering hyperglycemia, and in preserving insulin secretion in TAC-induced DM, and this is related to the increased bioavailability of $\mathrm{CoQ}_{10}-\mathrm{W}$. However, pancreatic $\mathrm{CoQ}_{10}$ levels were not significantly different in the two groups. Thus, the improved control of hyperglycemia or insulin secretion in the $\mathrm{CoQ}_{10}-\mathrm{W}$ group compared with the $\mathrm{CoQ}_{10}-\mathrm{L}$ group seems to be related to a systemic antioxidant effect rath-

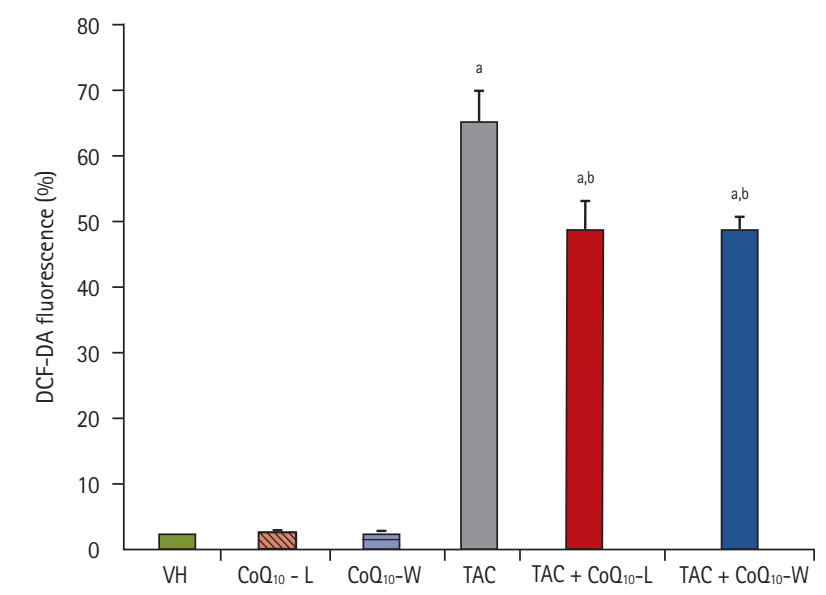

B

Figure 10. Comparison of reactive oxygen species $(R O S)$ production with coenzyme $\mathrm{Q}_{10}\left(\mathrm{CoQ}_{10}\right)-\mathrm{L}$ and $\mathrm{Co} \mathrm{Q}_{10}-\mathrm{W}$ treatments of tacrolimus (TAC)-induced insulinoma (INS) cell injury. Intracellular ROS production was measured using flow cytometry. (A) 2', 7'-Dichlorofluorescin-diacetate (DCF-DA) was used as a probe to evaluate alterations in intracellular ROS, and (B) quantitative analysis of ROS production was carried out. Data are presented as mean \pm standard error $(\mathrm{n}=9)$. One-way analysis of variance was used to analyze the data. $\mathrm{VH}$, vehicle; $T A C+\mathrm{CoQ}_{10}-\mathrm{L}$, TAC cotreatment with lipid-soluble coenzyme $\mathrm{Q}_{10} ; \mathrm{TAC}+\mathrm{CoQ} \mathrm{T}_{10}-\mathrm{W}$, TAC cotreatment with water-soluble coenzyme $\mathrm{Q}_{10} ; \mathrm{SSC}-\mathrm{H}$, side scatter height. ${ }^{\mathrm{a}} \mathrm{p}<0.05 \mathrm{vs}$. VH. ${ }^{\mathrm{b}} \mathrm{p}<0.05 \mathrm{vs}$. TAC. 
er than its local effect on pancreatic tissue. This presumption may be supported by the lack of difference in cell survival or ROS production in in vitro studies of the two groups.

It is well known that oxidative stress $[4,24,25]$ and apoptosis [25-27] are common mechanisms of TAC-induced DM. To explain the improved hyperglycemia control by $\mathrm{CoQ}_{10}-\mathrm{W}$, we evaluated the antioxidant and anti-apoptotic effects of $\mathrm{CoQ}_{10}-\mathrm{W}$ and $\mathrm{CoQ}_{10}-\mathrm{L}$ in TAC-induced pancreatic islet injury. The results of our study clearly demonstrate that $\mathrm{CoQ}_{10}-\mathrm{W}$ reduced both, the TAC-induced markers of oxidative stress (8-OHdG in tissue and serum, 4-HHE in tissue), and TAC-induced apoptosis to a greater extent than $\mathrm{CoQ}_{10}-\mathrm{L}$. These findings confirm that $\mathrm{CoQ}_{10}-\mathrm{W}$ has better antioxidant and anti-apoptotic effects than $\mathrm{CoQ}_{10}$-L on TAC-induced pancreas injury, and this may explain the better hyperglycemia control of $\mathrm{CoQ}_{10}$-W than $\mathrm{CoQ}_{10}$-L.

Oxidative stress is closely related to the quantity and quality of mitochondria $[28,29]$. High-quality mitochondria protect cells against oxidative stress and prevent apoptosis [29]. In our data, $\mathrm{CoQ}_{10}-\mathrm{L}$ increased number of insulin granules compared with the TAC group, with $\mathrm{CoQ}_{10}-\mathrm{W}$ producing a further increase as shown by electron microscopy. Furthermore, $\mathrm{CoQ}_{10}-\mathrm{W}$ increased the average mitochondria area over that seen in the TAC group. Although $\mathrm{CoQ}_{10}-\mathrm{L}$ also restored the loss of mitochondria, it was significantly less effective than $\mathrm{CoQ}_{10}-\mathrm{W}$. These findings suggest that the improved antioxidant capacity of $\mathrm{CoQ}_{10}-\mathrm{W}$ offers a more effective remedy for islet and mitochondrial damage than $\mathrm{CoQ}_{10}$-L in the TAC-induced DM model.

Our study has some limitations. First, the $\mathrm{CoQ}_{10}-\mathrm{W}$ group had a similar $\mathrm{CoQ}_{10}$ level in the pancreas as the $\mathrm{CoQ}_{10}-\mathrm{L}$ group, and in vitro study revealed that viability and ROS production of islet cells in the $\mathrm{CoQ}_{10}-\mathrm{L}$ and $\mathrm{CoQ}_{10}$-W groups were not significantly. Further studies are needed to improve the action of $\mathrm{CoQ}_{10}-\mathrm{W}$ at the cellular level. Second, we compared the $\mathrm{CoQ}_{10}$ levels at the end of our study. However, endogenous substances such as $\mathrm{CoQ}_{10}$ follow the circadian rhythm. Thus, pharmacokinetic and pharmacodynamic studies are needed to determine whether $\mathrm{CoQ}_{10}-\mathrm{W}$ has better bioavailability than $\mathrm{CoQ}_{10}-\mathrm{L}$. Third, we did not include the $\mathrm{VH}$ of nano-emulsion without $\mathrm{CoQ}_{10}$. Therefore, there is a concern that that anti-inflammatory effect of EPA in na- no-emulsion may affect that of $\mathrm{CoQ}_{10}-\mathrm{W}$. In this point, we previously tested the anti-inflammatory effect of EPA in rheumatoid arthritis model, and found that EPA in nano-emulsion did not affect the anti-inflammatory effect of $\mathrm{CoQ}_{10}$ (data not shown). Thus, the anti-inflammatory effect of EPA in nano-emulsion may be ruled out in our study.

In summary, the improved $\mathrm{CoQ}_{10}$ bioavailability using $\mathrm{CoQ}_{10}$-W may provide more benefit than conventional $\mathrm{CoQ}_{10}$ in TAC-induced diabetes. We expect that adding $\mathrm{CoQ}_{10}$-W TAC treatments can effectively reduce TAC-induced oxidative stress in clinical practice.

\section{KEY MESSAGE}

1. Water-soluble coenzyme $\mathrm{Q}_{10}\left(\mathrm{Co}_{10}\right)$ improves bioavailability compared to conventional lipid-soluble $\mathrm{CoQ}_{10}$.

2. Water-soluble $\mathrm{CoQ}_{10}$ reduces oxidative stress more effectively than lipid-soluble $\mathrm{CoQ}_{10}$.

3. Treatment with a combination of water-soluble $\mathrm{CoQ}_{10}$ and tacrolimus provides effect protection against tacrolimus-induced pancreatic islet injury.

\section{Conflict of interest}

No potential conflict of interest relevant to this article was reported.

\section{Acknowledgments}

This study was supported by a grant of the Korean Health Technology R\&D Project, Ministry for Health and Welfare, Republic of Korea ( $\mathrm{HI}_{14} \mathrm{C}_{3417}$ ) and the Bio \& Medical Technology Development Program of the National Research Foundation (NRF) \& funded by the Korean government (MSIT) (NRF-2019M3A9A8064802).

\section{REFERENCES}

1. Jin DC, Yun SR, Lee SW, et al. Current characteristics of dialysis therapy in Korea: 2016 registry data focusing on diabetic patients. Kidney Res Clin Pract 2018;37:20-29.

2. Valderhaug TG, Hjelmesaeth J, Hartmann A, et al. The association of early post-transplant glucose levels with 
long-term mortality. Diabetologia 2011;54:1341-1349.

3. Sharif A. Preventing and managing hyperglycemia in kidney transplant patients. Curr Opin Nephrol Hypertens 2012;21:574-579.

4. Jin J, Jin L, Luo K, Lim SW, Chung BH, Yang CW. Effect of empagliflozin on tacrolimus-induced pancreas islet dysfunction and renal injury. Am J Transplant 2017;17:26012616.

5. Zhang LY, Jin J, Luo K, et al. Shen-Kang protects against tacrolimus-induced renal injury. Korean J Intern Med 2019;34:1078-1090.

6. Lenaz G, Fato R, Formiggini G, Genova ML. The role of Coenzyme $\mathrm{Q}$ in mitochondrial electron transport. Mitochondrion 2007;7 Suppl:S8-S33.

7. Negida A, Menshawy A, El Ashal G, et al. Coenzyme Q10 for patients with Parkinson's disease: a systematic review and meta-analysis. CNS Neurol Disord Drug Targets 2016;15:45-53.

8. Huo J, Xu Z, Hosoe K, et al. Coenzyme Q1o prevents senescence and dysfunction caused by oxidative stress in vascular endothelial cells. Oxid Med Cell Longev 2018;2018:3181759.

9. Ozcan P, Fiçicioglu C, Kizilkale O, et al. Can Coenzyme Q10 supplementation protect the ovarian reserve against oxidative damage? J Assist Reprod Genet 2016;33:12231230.

10. Prangthip P, Kettawan A, Posuwan J, Okuno M, Okamoto T. An improvement of oxidative stress in diabetic rats by ubiquinone-10 and ubiquinol-10 and bioavailability after short- and long-term Coenzyme Q10 supplementation. J Diet Suppl 2016;13:647-659.

11. Ulla A, Mohamed MK, Sikder B, et al. Coenzyme Q1o prevents oxidative stress and fibrosis in isoprenaline induced cardiac remodeling in aged rats. BMC Pharmacol Toxicol 2017;18:29.

12. Xue R, Yang J, Wu J, Meng Q, Hao J. Coenzyme Q1o inhibits the activation of pancreatic stellate cells through $\mathrm{PI}_{3} \mathrm{~K} /$ AKT/mTOR signaling pathway. Oncotarget 2017;8:9230092311.

13. Sun IO, Jin L, Jin J, Lim SW, Chung BH, Yang CW. The effects of addition of coenzyme Q1o to metformin on sirolimus-induced diabetes mellitus. Korean J Intern Med 2019;34:365-374.

14. Bauerova K, Paulovicova E, Mihalova D, et al. Combined methotrexate and coenzyme $Q_{10}$ therapy in adjuvant-induced arthritis evaluated using parameters of inflamma- tion and oxidative stress. Acta Biochim Pol 2010;57:347-354.

15. Hwang H, Ghee JY, Song JH, Piao S, Yang CW. Comparison of adverse drug reaction profiles of two tacrolimus formulations in rats. Immunopharmacol Immunotoxicol 2012;34:434-442.

16. Visconti GL, Mazzoleni L, Rusconi C, et al. Determination by UPLC/MS-MS of Coenzyme Q10 (CoQ10) in plasma of healthy volunteers before and after oral intake of food supplements containing CoQ10. J Anal Bioanal Tech 2015;:S13:011.

17. Jin J, Lim SW, Jin L, et al. Effects of metformin on hyperglycemia in an experimental model of tacrolimus- and sirolimus-induced diabetic rats. Korean J Intern Med 2017;32:314-322.

18. Lim SW, Jin L, Luo K, et al. Klotho enhances FoxO3-mediated manganese superoxide dismutase expression by negatively regulating $\mathrm{PI}_{3} \mathrm{~K} / \mathrm{AKT}$ pathway during tacrolimus-induced oxidative stress. Cell Death Dis 2017;8:e2972.

19. Peng YM, Zheng JB, Zhou YB, Li J. Characterization of a novel curcumin analog $\mathrm{P} 1$ as potent inhibitor of the NF- $\mathrm{KB}$ signaling pathway with distinct mechanisms. Acta Pharmacol Sin 2013;34:939-950.

20. Borowy-Borowski H, Sodja C, Docherty J, Walker PR, Sikorska M. Unique technology for solubilization and delivery of highly lipophilic bioactive molecules. J Drug Target 2004;12:415-424.

21. Liu ZX, Artmann C. Relative bioavailability comparison of different coenzyme Q1o formulations with a novel delivery system. Altern Ther Health Med 2009;15:42-46.

22. Martinefski M, Samassa P, Buontempo F, Hocht C, Lucangioli S, Tripodi V. Relative bioavailability of coenzyme Q10 formulation for paediatric individualized therapy. J Pharm Pharmacol 2017;69:567-573.

23. Bhagavan HN, Chopra RK. Plasma coenzyme Q10 response to oral ingestion of coenzyme Q10 formulations. Mitochondrion 2007;7 Suppl:S78-S88.

24. Lim SW, Jin L, Luo K, Jin J, Yang CW. Ginseng extract reduces tacrolimus-induced oxidative stress by modulating autophagy in pancreatic beta cells. Lab Invest 2017;97:12711281.

25. Jin L, Lim SW, Jin J, et al. Effect of conversion to CTLA4Ig on tacrolimus-induced diabetic rats. Transplantation 2018;102:e137-e146.

26. Lim SW, Jin L, Jin J, Yang CW. Effect of exendin-4 on autophagy clearance in beta cell of rats with tacrolimus-induced diabetes mellitus. Sci Rep 2016;6:29921. 
27. Constantinescu AA, Abbas M, Kassem M, et al. Differential influence of tacrolimus and sirolimus on mitochondrial-dependent signaling for apoptosis in pancreatic cells. Mol Cell Biochem 2016;418:91-102.

28. Smith RA, Adlam VJ, Blaikie FH, et al. Mitochondria-tar- geted antioxidants in the treatment of disease. Ann N Y Acad Sci 2008;1147:105-111.

29. Sinha K, Das J, Pal PB, Sil PC. Oxidative stress: the mitochondria-dependent and mitochondria-independent pathways of apoptosis. Arch Toxicol 2013;87:1157-1180. 